\title{
The study of $\mathrm{CaO}$ and $\mathrm{MgO}$ heterogenic nano-catalyst coupling on transesterification reaction efficacy in the production of biodiesel from recycled cooking oil
}

\author{
Kambiz Tahvildari ${ }^{1}$, Yasaman Naghavi Anaraki ${ }^{1}$, Reza Fazaeli ${ }^{2}$, Sogol Mirpanji ${ }^{1}$ and Elham Delrish ${ }^{3 *}$
}

\begin{abstract}
Background: Fossil fuels' pollution and their non-renewability have motivated the search for alternative fuels. Some common example of seed oils are sunflower oil, date seed oil, soy bean oil. For instance, soy methyl and soy-based biodiesel are the main biodiesel. Biodiesel is a clean diesel fuel that can be produced through transesterification reaction. Recycled cooking oil, on the other hand, is one of the inexpensive, easily available sources for producing biodiesel.

Results: This article is aimed at production of biodiesel via trans-esterification method, Nano $\mathrm{CaO}$ synthesis using sol-gel method, and Nano MgO synthesis using sol-gel self-combustion. Two catalysts' combination affecting the reaction's efficacy was also discussed. Optimum conditions for the reaction in the presence of Nano $\mathrm{CaO}$ are $1.5 \%$ weight fracture, 1:7 alcohol to oil proportion and $6 \mathrm{~h}$ in which biodiesel and glycerin (the byproduct) are produced. Moreover, the optimum conditions for this reaction in the presence of $\mathrm{Nano} \mathrm{CaO}$ and $\mathrm{Nano} \mathrm{MgO}$ mixture are $3 \%$ weight fracture (0.7 g of Nano $\mathrm{CaO}$ and $0.5 \mathrm{~g}$ of Nano MgO), 1:7 alcohols to oil proportion and $6 \mathrm{~h}$.

Conclusions: Nano MgO is not capable of catalyzing the transesterification by itself, because it has a much weaker basic affinity but when used with $\mathrm{Nano} \mathrm{CaO}$ due to its surface structure, the basic properties increase and it becomes a proper base for the catalyst so that $\mathrm{CaO}$ contact surface increases and transesterification reaction yield significantly increases as well. This study investigates the repeatability of transesterification reaction in the presence of these Nano catalysts as well.
\end{abstract}

Keywords: Biodiesel production, Heterogenic Nano-catalyst, Recycled cooking oil, Transesterification reaction

\section{Introduction}

Today, the growing need for new energy sources in transportation is one of the primary challenges for different countries. Scientists are compelled to find alternatives to currently used fuels because of their decreased purification capacity; pollution caused by fossil fuels, their limited life span, and increased prices. Mono alkyl ester biodiesel is a clean diesel fuel that can be manufactured by fresh or used vegetable oils or even animal fats and waste oils. This fuel is made from renewable sources

\footnotetext{
* Correspondence: delrish.elham@gmail.com

${ }^{3}$ Nano-ophthalmology Department, Stem Cells Preparation Unit, Eye Research Center, Farabi Eye Hospital, Tehran University of Medical Sciences, Tehran, Iran

Full list of author information is available at the end of the article
}

and is biodegradable [1-3]. Transesterification method or green process is one way of producing biodiesels. In this method, vegetable oils are added to an alcohol (usually methanol) producing esters. It is noteworthy that glycerol is the byproduct of this reaction which greatly contributes to the pharmaceutical science and cosmetic products [4].

Parameters affecting transesterification procedure are: reaction temperature, alcohol-oil mole proportion, humidity, free fatty acids, mixing speed, alcohol type, reaction duration, catalyst type and amount [5-7]. Catalysts used in transesterification procedure are categorized into 3 groups: homogenic catalysts, heterogenic catalysts, and biocatalysts [8, 9]. The limitations of homogenic 
catalysts have resulted in the dominant use of the heterogenic catalysts. Heterogenic catalysts and reactants are in separate phases and are divided into acidic and basic solid catalysts. $\mathrm{ZrO}$ and $\mathrm{TiO}$ are examples of acidic solid catalysts, while $\mathrm{MgO}$ and $\mathrm{CaO}$ are among the basic solid ones $[10,11]$. It is worthy to mention that basic solid catalysts happen to be more effective than the acidic ones because they do not require high temperature and pressure, thus react more rapidly, have fewer side reactions, have no oxidation, and are more available and cost-effective [12, 13]. Heterogenic catalysts are beneficial in many ways: a) They decrease soaping problems and water usage, b) they do not mix with methanol or ethanol, c) they are easy to separate from biodiesel and glycerol, d) they are recyclable and can be reused many times, e) they are environmentally compatible and can be used in continuous and non-continuous procedures, $f$ ) they have low sensitivity to free fatty acids because of the stability of their surface microcrystal structure, and g) their quality of biodiesel is high, although they convert triglyceride to biodiesel rather slowly $[14,15]$.

In fact, the most important problem in producing biodiesel is its high cost which depending on the primal raw material can be 1.5 times the prices of petroleum diesel. Reports? almost $80 \%$ of the total biodiesel cost comes from primal materials cost which are vegetable oils or animal fats. Thus, using burnt food oil decreases the related costs in producing biodiesel because of its availability and inexpensiveness. In addition, environmental pollution is lessened by recycling used cooking oils [16-18]. Used cooking oils have characteristics that make them different rather than vegetable oils or animal fats. High cooking temperature and food water hydrolyze triglycerides produce lots of free fatty acids. Reaction between these free fatty acids and water can form soaps and reduce biodiesel efficacy. Free fatty acids make up $0.5-15 \%$ of used cooking oil weight, although the proper amount for transesterification reaction is less than $0.5 \%$ of weight percentage $[19,20]$.

Basic heterogenic catalysts are divided into metallic oxides and their derivatives. $\mathrm{CaO}$ is one type of basic heterogenic catalysts which is most widely used for transesterification reaction because it is highly basic, and has a low solubility in methanol; it can be synthesized from inexpensive sources such as lime stone and calcium hydroxide and generates low bioenvironmental pollution. Nanocatalysts have high specific surface and degeneration activity. Other studies have shown that high specific surface and large porosity is beneficial for the catalyst to bond with the sub-layer which enhances the efficacy of transesterification reaction. One way to produce Nano $\mathrm{CaO}$ is to saturate lithium on $\mathrm{CaO}$ through wet method. It is suggested that a 12:1 proportion of methanol to oil at $65 \mathrm{C}$ heat in $2 \mathrm{~h}$ using $5 \%$ weight of the catalyst for esterification of jatropha oil has a yield over $99 \%$ [21].

The first basic heterogenic catalyst in pilot scale used for transesterification reaction was $\mathrm{MgO}$ [18]. Other studies have indicated that $\mathrm{MgO}$ has a fine efficacy in non-continuous reactions. Production costs of biodiesel products in a discontinuous reactor decrease in the presence of $\mathrm{MgO}$. $\mathrm{MgO}$ has a high yield in highly critical conditions and in a high proportion of methanol to oil $[11,22]$. The following results are achieved in other studies concerning $\mathrm{MgO}$ catalyst (Table 1) [10].

Nano MgO exhibits a high yield for soy oil transesterification reaction in the presence of super critical methanol. This catalyst's solubility and penetration plays an essential role in enhancing the reaction efficacy, which also can be adjusted by mixing two catalysts. For instance, $90 \%$ yield is achieved by soy oil in a 10-min reaction, using 36:1 methanol to oil ratio, $533 \mathrm{~K}$ temperature, $3 \%$ weight catalyst, and $1000 \mathrm{rpm}[23,24]$.

Another tranesterification reaction was performed on cotton seed oil, in the presence of $14.4 \%$ weight $\mathrm{CaO}-\mathrm{MgO}$ catalyst, loaded on $\mathrm{Al} 2 \mathrm{O} 3$, using 12:24 methanol to oil ratio, $95.63{ }^{\circ} \mathrm{C}$ temperature, and $97.62 \%$ yield was achieved. Two types of commercial nanopowder calcium oxides were studied in order to discuss the transesterification reaction of canola oil: Nanopowder exhibiting a higher surface area (HSA nano- $\mathrm{CaO}$ ) and nanopowder exhibiting a moderate surface area (nano-CaO). The effects of reaction temperature, catalyst/oil weight ratio, and methanol/ oil molar ratio on the reaction's conditions were studied. The results claim that nanopowder $\mathrm{CaOs}$ present a higher activity than the other type, due to their larger BET surface areas. At $65{ }^{\circ} \mathrm{C}, 99.85 \%$ biodiesel yield was obtained by 3 wt. \% of the nano-CaO

Table 1 The efficacy of methyl ester using MgO as catalyst

\begin{tabular}{|c|c|c|c|c|c|c|}
\hline Type of Oil & Surface Area $\left(\mathrm{M}^{2} / \mathrm{g}\right)$ & $\begin{array}{l}\text { Reaction's Temperature } \\
\left({ }^{\circ} \mathrm{C}\right)\end{array}$ & $\begin{array}{l}\text { Molar ratio } \\
\text { Methanol/oil }\end{array}$ & $\begin{array}{l}\text { Reaction's Duration } \\
\text { (hour) }\end{array}$ & Catalyst concentration (\% W/W) & Efficiency \\
\hline Linseed Oil & 300 & Methanol-Reflux & $75: 1$ & 22 & $10 \%$ & $64 \%$ \\
\hline Soybean Oil & 36 & 180 & $12: 1$ & 1 & $5 \%$ & $72 \%$ \\
\hline Soybean Oil & 229 & 180 & $12: 1$ & 1 & $5 \%$ & $90 \%$ \\
\hline
\end{tabular}




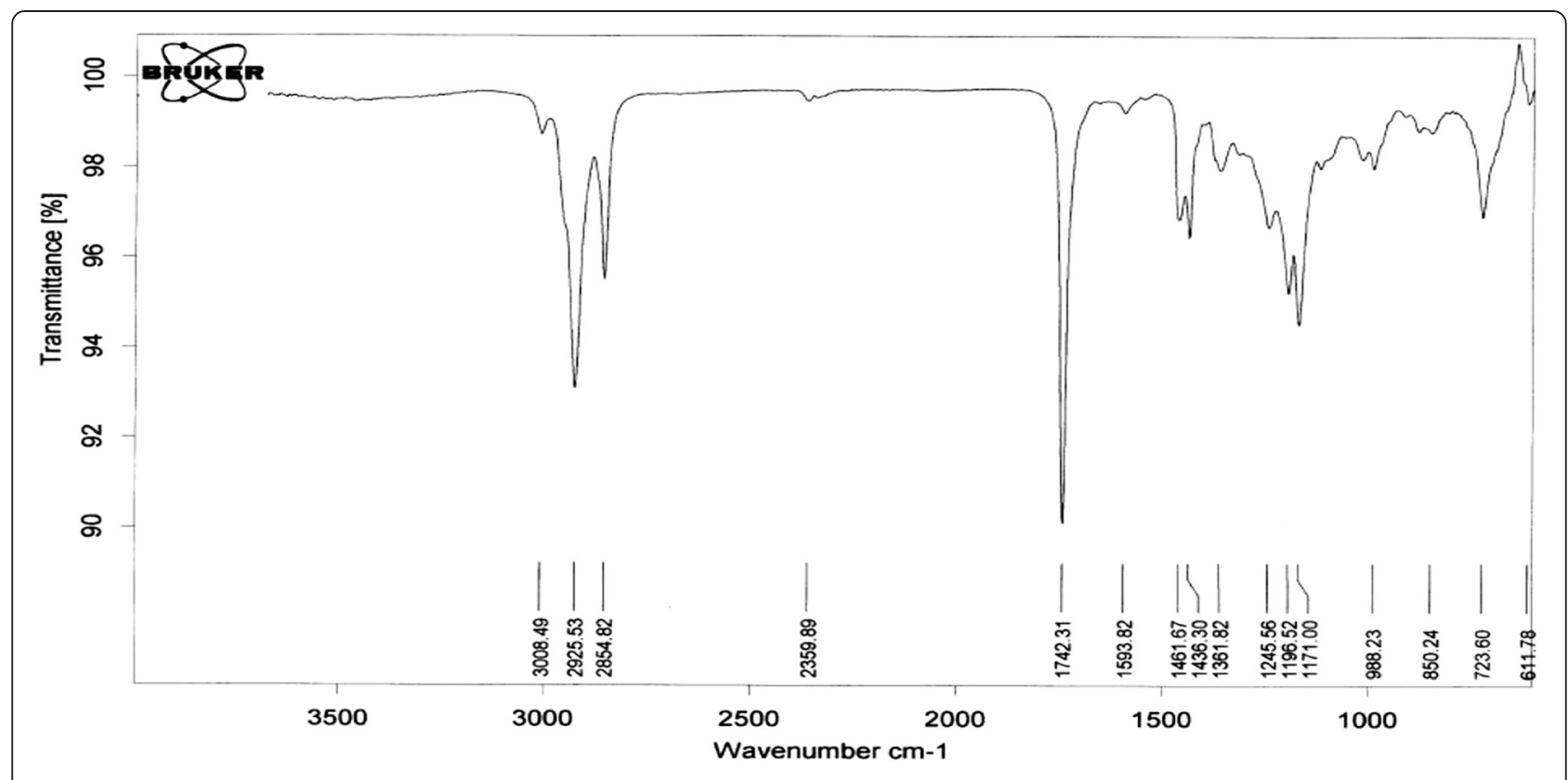

Fig. 1 Characteristics of synthetic Nano CaO: (a) SEM image; (b) XRD spectrum

catalyst, and 9:1 methanol/oil molar ratio, in $2 \mathrm{~h}$. The required catalyst/oil weight ratio in order to achieve the same yield under the same conditions, was 10 times less in the HSA-nano-CaO catalyst's case [25].

In this study, Nano $\mathrm{CaO}$ and $\mathrm{Nano} \mathrm{MgO}$ were synthesized, using sedimentation method and sol-gel selfcombustion, respectively. While the next step was progressing, transesterification reaction was performed and examined in different ways with various proportions of catalyst weight and mole proportion of alcohol to oil. Also, catalyst repeatability was assessed. This study was aimed at comparing the efficacy of the reaction with and without catalysts by coupling Nano $\mathrm{CaO}$ and Nano $\mathrm{MgO}$. Using a combination of 2 catalysts ( $\mathrm{MgO}$ and $\mathrm{CaO}$ ) results in an enhanced basic strength and contact surface. Subsequently, the reaction is performed more gently and is more repeatable.

\section{Experimental \\ Materials}

Analytical reagent (AR) grade calcium nitrate, ammonia, urea, sodium hydroxide, potassium hydroxide, magnesium sulfate, methanol, 2-propanol, and phenolphthalein were purchased from Merck. Co. Ethylene glycol and magnesium nitrate used in this study were obtained from Aldrich. Co. Moreover, home waste cooking oil was also provided. All other chemicals were obtained commercially and of analytical grade No additional purification was done on materials.
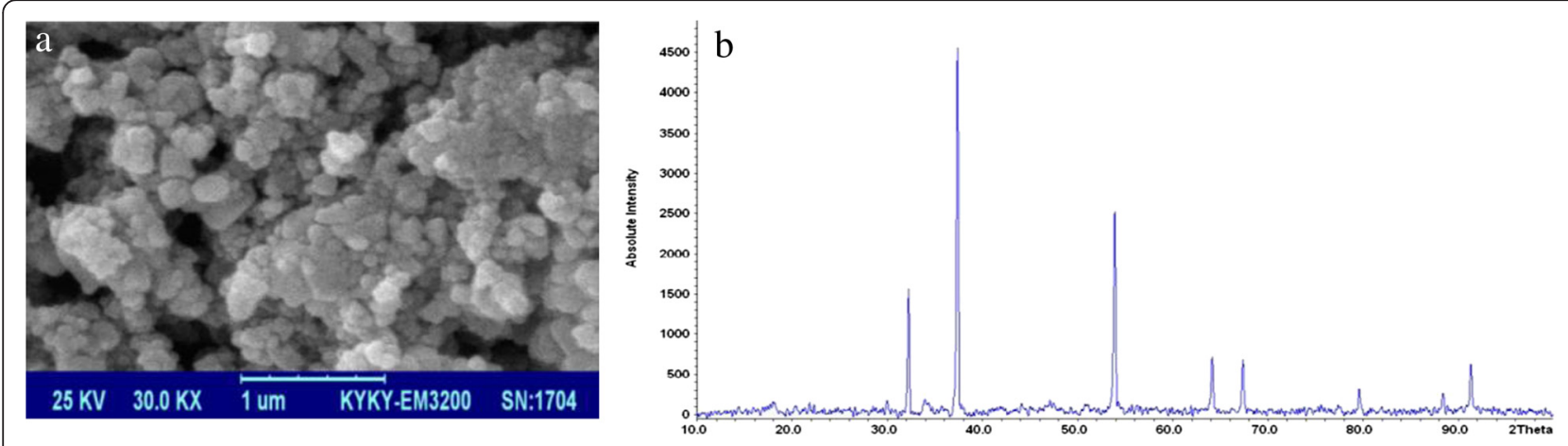

Fig. 2 Characteristics of synthetic Nano MgO: (a) SEM image; (b) XRD spectrum 

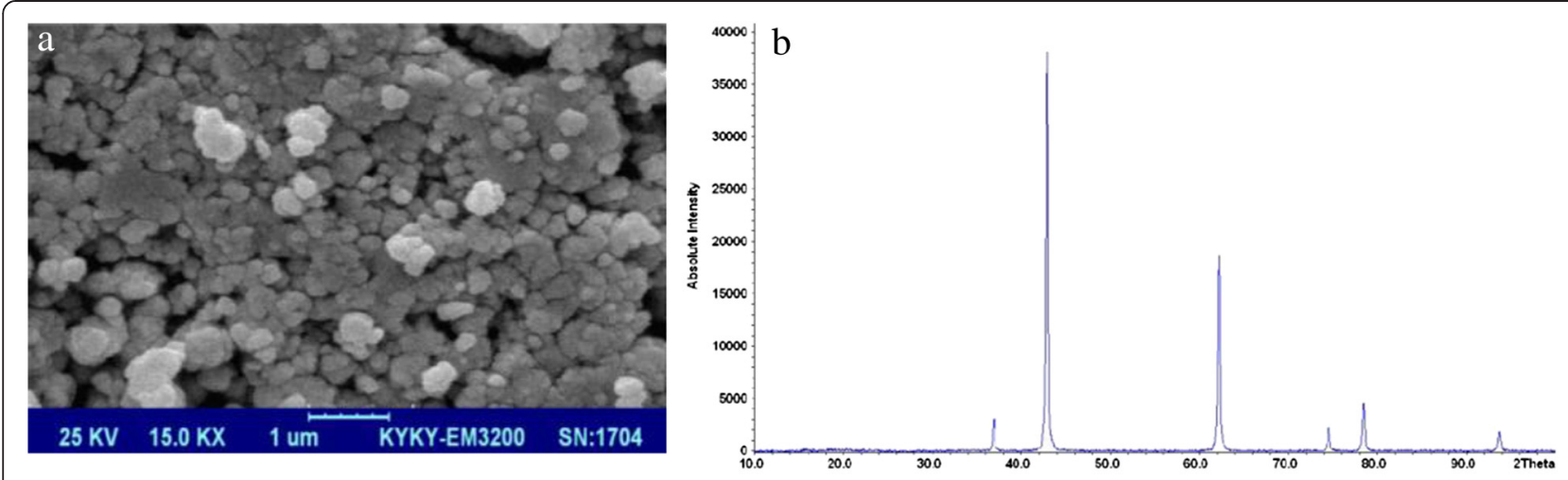

Fig. 3 Biodiesel FTIR spectrum in the presence of Nano CaO

\section{Apparatus}

Oven temperature programmed (up to $1200 \mathrm{C}$ ), X-ray diffraction (XRD) (STADI-P, STOE, Germany), scanning electron microscope (SEM) (Kyky 3200, China), field emission scanning electron microscope (FESEM) (S-4160, Hitachi, Japan), IKA-WERKE-EUROSTAR digital mechanical mixer (Germany, 50-2000 rpm), and Fourier transform infrared spectrometer (FTIR) (BRUKER, TENSOR2, Germany) were provided for conducting the study.

\section{Catalyst preparation}

\section{Nano CaO synthesis using sol-gel method}

Firstly, 11.81 grams calcium nitrate. $4 \mathrm{H}_{2} \mathrm{O}$ was dissolved in minimum amount of water and then it was added to $25 \mathrm{ml}$ of ethylene glycol being mixed by mechanical mixer. Two grams of $\mathrm{NaOH}$ was dissolved in $25 \mathrm{ml}$ of purified water, added drop by drop, as the mixing took place. The produced mixture was mixed for $2 \mathrm{~h}$ so that a clear white gel was obtained. The white gel was kept still for $2 \mathrm{~h}$ for the reaction to complete. Then after 4 times of being washed with water, $\mathrm{NaOH}$ was excreted and $\mathrm{pH}$ was adjusted at about 10. After that, the gel was heated up to $80{ }^{\circ} \mathrm{C}$ for $2 \mathrm{~h}$ so that the water could be vaporized and the gel concentrated. The concentrated gel was placed in a desiccator for one hour to dry completely. The resulting dry gel was milled in the form of a white powder. The produced powder was put in the cruse and into the oven which was gradually heated up to $800{ }^{\circ} \mathrm{C}$ and stayed so for an hour for decarbonization.

\section{Nano MgO synthesis using sol-gel self-combustion with urea fuel}

Initially, $21.58 \mathrm{~g}$ of magnesium nitrate. $6 \mathrm{H}_{2} \mathrm{O}$ and $10.16 \mathrm{~g}$ of urea were dissolved in non-ionized water at the mole ration of 1:2. Ammonia was added drop by drop till $\mathrm{pH}$ of the mixture was 7 . The system was placed in a 60$70{ }^{\circ} \mathrm{C}$ water bath and stirred by a mixer to allow the water and mobile materials present in the mixture to evaporate. As water vaporized, the solution was concentrated and became viscose. The resulting gel underwent self-combustion; as a result, it started boiling and surfaced the walls of the crucible. Subsequently, a thermo genic reaction took place and a lateritious gas was emitted. This reaction left a white porous mass. $\mathrm{NO}_{3}^{-}$ions in the compound created an oxidative environment for the degradation of organic mixtures. In order to eliminate the remaining organic material, the powder from selfcombustion reaction must be de-carbonized at higher temperatures. Next, the powder was fined and put in a furnace $\left(600{ }^{\circ} \mathrm{C}\right.$ for $\left.2 \mathrm{~h}\right)$ to de-carbonize.

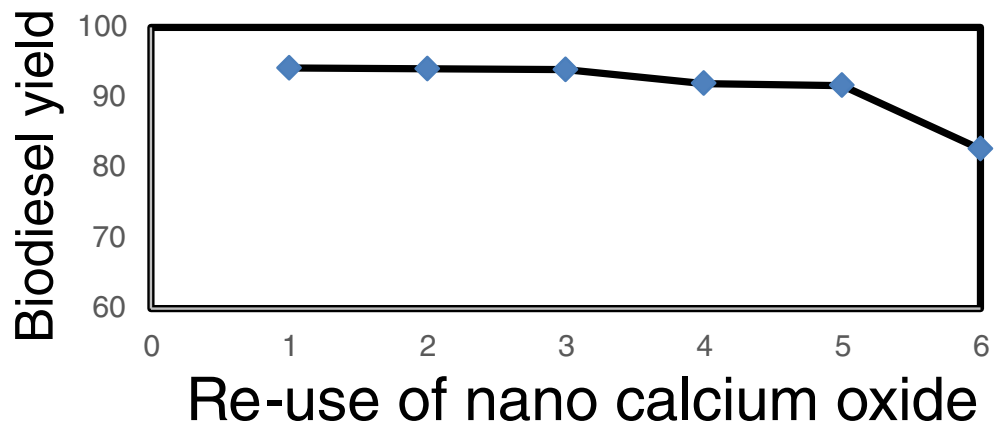

Fig. 4 The efficacy of biodiesel production in six repetitions of $\mathrm{Nano} \mathrm{CaO}$ 


\section{Catalyst characterization}

To investigate the structure and crystallinity of the catalysts, the X-ray diffraction analysis was conducted. Morphology and the mean particle size of the catalysts were analyzed by SEM and XRD spectrums. In addition, the microstructure was characterized by field emission scanning electron microscopy.

\section{Transesterification reaction of cooking waste oil using} methanol in presence of synthetized Nano $\mathrm{CaO}$

The yield for waste cooking oil transesterification reaction in the presence of Nano $\mathrm{CaO}$ catalyst has been examined according to previous studies [16, 17].

Overall, $40 \mathrm{~g}$ of waste oil was filtered using Buchner funnel in vacuity and then $0.5 \mathrm{~g} \mathrm{MgSO} 4$ was added while mixing to trap the Water mixed with oil. After filtering the waterless oil was poured into a $100 \mathrm{ml}$ flask using stirrer and it was heated to $55{ }^{\circ} \mathrm{C}$ for $20 \mathrm{~min}$. Then 0.4 , 0.6 , and $1.2 \mathrm{~g}$ of the catalyst and $8.76,10.22$, and $11.69 \mathrm{~g}$ of methanol were added to it. The heater was warmed to $75{ }^{\circ} \mathrm{C}$ so that methanol reflux was engaged. After 4 and $6 \mathrm{~h}$, the mixture was moved to a decanter and over time 2 phases were shaped.

The final products of this reaction are biodiesel and combined glycerin with Nano $\mathrm{CaO}$.

The upper phase was biodiesel and the lower was combined glycerin with Nano $\mathrm{CaO}$.

The phases were separated and the biodiesel was returned to the decanter for washing. Then, 40mls of the $80^{\circ}$ water was added to the biodiesel so that its $\mathrm{pH}$ reached 7. Moreover, the water used in this process was clear and neutral after the first washing. The produced biodiesel had some amount of water and magnesium sulfate was used to absorb it. Then the waterless biodiesel was separated from $\mathrm{MgSO}_{4}$ by centrifuge. In order to check the purity, IR spectrums of biodiesel and oil were compared (Fig. 1).

\section{The tranesterfication reaction of cooking waste oil using methanol in the presence of synthetized Nano $\mathrm{MgO}$ via self-combustion method}

The yield for waste cooking oil transesterification reaction in the presence of Nano $\mathrm{MgO}$ catalyst using selfcombustion was studied with alcohol-oil proportions of $1: 30,1: 20,1: 12,1: 7$, and $1: 6$ and $1.5,3,5$ and $10 \%$ weight catalyst during 6 and $12 \mathrm{~h}$. It should be noted that yield was not sufficient in any of these conditions. Ten grams of waste oil was filtered using Buchner funnel in vacuity and then $0.5 \mathrm{~g}$ of magnesium sulfate was added while mixing to trap the oil water. After filtering the waterless oil was poured in a $100 \mathrm{ml}$ flask with a magnet, it was heated to $55^{\circ} \mathrm{C}$ for $20 \mathrm{~min}$. Then $0,0.5,1$, 0.5 , and $3.1 \mathrm{~g}$ of the catalyst and $2.2,4.28,10.7,14.61$, 55.19 , and $95.4 \mathrm{~g}$ of methanol were added to it. The

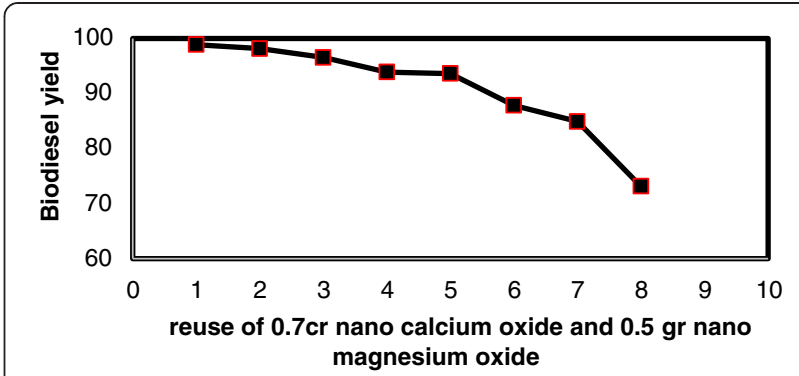

Fig. 5 The efficacy of biodiesel production in eight repetitions of $\mathrm{CaO}(0.7 \mathrm{~g})+\mathrm{MgO}(0.5 \mathrm{~g})$ Nanocatalysts

heater was warmed to $75^{\circ} \mathrm{C}$ so that methanol reflux was engaged. After $12 \mathrm{~h}$, the mixture was moved to the decanter but only a single yellow oily phase was formed under which was the catalyst.

It showed that transesterification reaction hadn't made any progress significantly in the presence of the catalyst.

\section{The trasnesterification reaction of cooking waste oil using methanol in the presence of a combination of Nano $\mathrm{CaO}$ and $\mathrm{MgO}$ prepared by self-combustion method}

The protocol for preparing oil was the same as what was explained earlier in this article only with the difference that here, $3 \%$ weight of self-combustion combination of the catalysts, $\mathrm{MgO}$ and $\mathrm{CaO}$, and 7:1 oil to alcohol proportion were used. The $3 \%$ weight meant $1.2 \mathrm{~g}$ of the catalysts mixture which was generated by changing the mass proportion of the two catalysts of the transesterification reaction.

\section{Recycling of catalyst}

Recycling Nano CaO catalyst and evaluating its repeatability in waste cooking oil transesterification reaction

After transesterification reaction and separation of the biodiesel from glycerol and the catalyst, the remaining catalyst was washed away with n-Hexane and placed in a $70^{\circ}$ oven for $2 \mathrm{~h}$ to dry. In the next step oil preparation and the reaction procedure were done as described. The catalyst could be used up to six times.

Table 2 The three main agent groups of biodiesel

\begin{tabular}{llll}
\hline Frequency $\left(\mathrm{cm}^{-1}\right)$ & $\begin{array}{l}\text { The Functional } \\
\text { Group }\end{array}$ & Type of Vibration & Intensity \\
\hline 1436 & $-\mathrm{O}-\mathrm{CH}_{3}$ & Bending & Moderate \\
1196.52 & $-\mathrm{O}-\mathrm{CH}_{3}$ & Rocking & Moderate \\
1171 & $-\mathrm{C}-\mathrm{O}-\left(\mathrm{CH}_{3}\right)$ & $\begin{array}{l}\text { Stretching motions } \\
\text { symmetric }\end{array}$ & High \\
& & Sym & \\
\hline
\end{tabular}




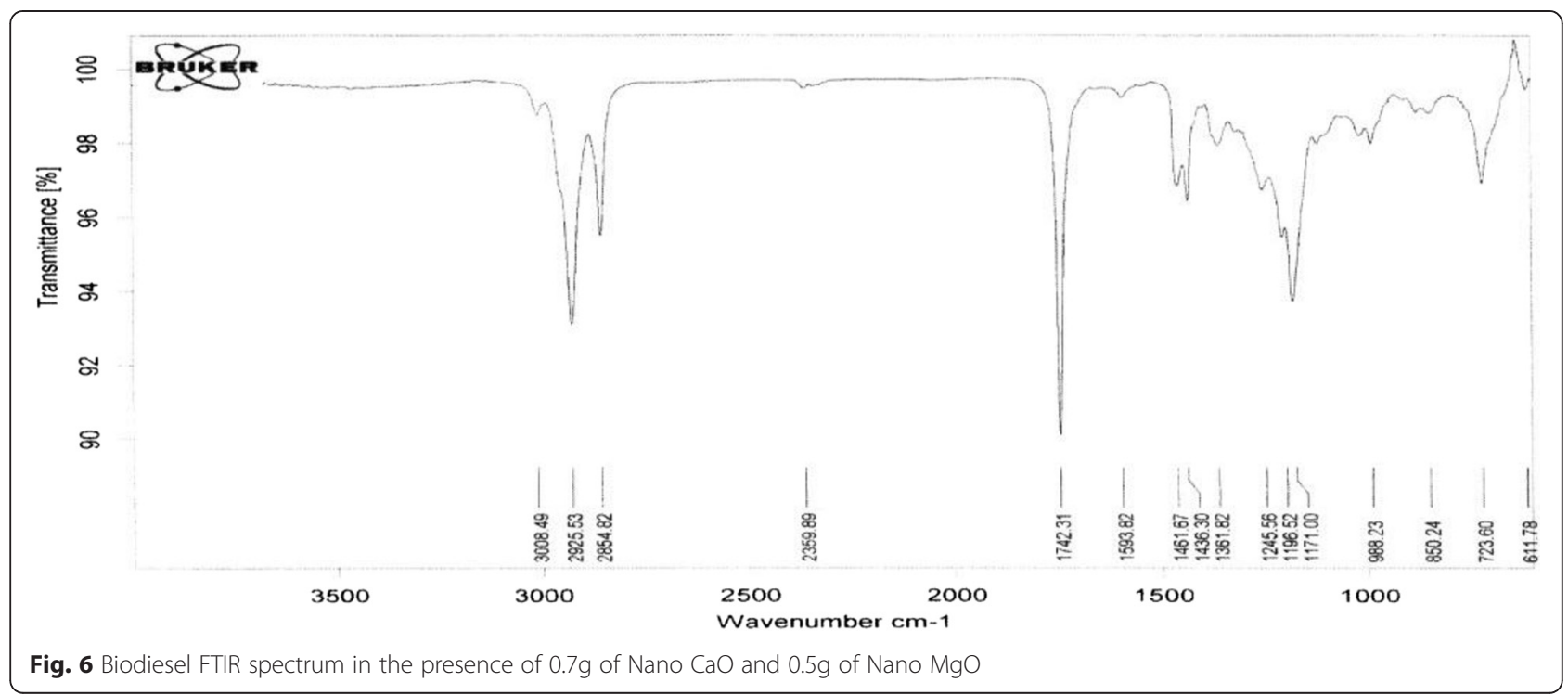

Recycling the catalysts Nano $\mathrm{CaO}(0.7 \mathrm{~g})$ and self-combustion Nano $\mathrm{MgO}(0.5 \mathrm{~g})$ and their repeatability in waste cooking oil transesterification

After transesterification reaction and separation of the biodiesel from glycerol and the catalyst, the remaining catalyst was washed away with $\mathrm{n}$-hexane and it was placed in a $70^{\circ}$ oven for $2 \mathrm{~h}$ to dry. In the next step, oil preparation and the reaction procedure were done as described earlier in this article. The catalyst mixture presented a repeatability of up to eight times.

\section{Results}

\section{Catalyst characterization}

SEM images indicated a spherical shape for the Nanoparticles (NPs) and $\mathrm{CaO}$ and $\mathrm{MgO}$ NPs were determined to be 65 and $70 \mathrm{~nm}$ in size. The application of XRD showed that the crystal structure of the particles was cubic. Additionally, the comparison of the obtained peaks and source peaks indicated that the Cao NPs were synthesized and average particle size was calculated $61 \mathrm{~nm}$ according to Scherer's equation (Fig. 2a, b). Also, the comparison of the obtained peaks and source peaks indicated that the Mgo NPs were synthesized and average particle size was calculated $69 \mathrm{~nm}$ according to Scherer's equation (Fig. 3a, b).

\section{Effect of Catalyst Compound on biodiesel yield}

Waste cooking oil transesterification reaction yield in the presence of synthesized Nano CaO catalyst

As described earlier in Section 2.5.1, this reaction was performed using different proportions of methanol to oil and various catalyst weight percentages. The results showed that 1:7 mol proportion for alcohol to oil and $1.5 \%$ weight catalyst over $6 \mathrm{~h}$ are the optimum conditions for this reaction. Biodiesel production mass yield is $94.37 \%$ in these optimum conditions (Table 3).

\section{Waste cooking oil transesterification reaction yield in the presence of synthesized Nano $\mathrm{MgO}$ catalyst}

Following the methods described in Section 2.5.2, this reaction was performed using different proportions of methanol to oil and various catalyst weight percentages. Nevertheless, transesterification reaction did not significantly progress in the presence of this catalyst.

Table 3 The efficacy of biodiesel production in the presence of synthetic Nano CaO catalyst

\begin{tabular}{|c|c|c|c|c|c|}
\hline The Amount of Oil (gr) & The Catalyst Compound & Alcohol: Oil Mole Ratio & $\begin{array}{l}\text { Mass Percent of the } \\
\text { Catalyst Compound }\end{array}$ & Reaction's Duration (hr) & Mass Efficiency \\
\hline 40 & $\mathrm{CaO}$ & $6: 1$ & $1 \%$ & 4 & 78.35 \\
\hline 40 & $\mathrm{CaO}$ & $6: 1$ & $1.5 \%$ & 4 & 80.12 \\
\hline 40 & $\mathrm{CaO}$ & $6: 1$ & $3 \%$ & 4 & 80.18 \\
\hline 40 & $\mathrm{CaO}$ & $7: 1$ & $1.5 \%$ & 4 & 92.39 \\
\hline 40 & $\mathrm{CaO}$ & $7: 1$ & $3 \%$ & 4 & 92.33 \\
\hline 40 & $\mathrm{CaO}$ & $8: 1$ & $1.5 \%$ & 4 & 92.36 \\
\hline 40 & $\mathrm{CaO}$ & $7: 1$ & $1.5 \%$ & 6 & 94.37 \\
\hline
\end{tabular}


Table 4 The efficacy of methyl ester using $\mathrm{CaO}$ as catalyst for 15 min

\begin{tabular}{lllll}
\hline Type of Oil & $\begin{array}{l}\text { Reaction's } \\
\text { Temperature }\left({ }^{\circ} \mathrm{C}\right)\end{array}$ & $\begin{array}{l}\text { Molar ratio } \\
\text { Methanol/oil }\end{array}$ & $\begin{array}{l}\text { Catalyst } \\
\text { concentration } \\
\text { (\% W/W) }\end{array}$ & Efficiency \\
\hline Linseed Oil & Methanol-Reflux & $4.5: 1$ & 0.8 & $10 \%$ \\
Linseed Oil & 192 & $41.1: 1$ & 3 & $50 \%$ \\
\hline
\end{tabular}

Waste cooking oil transesterification reaction yield in the presence of $3 \%$ combined Nano $\mathrm{CaO}$ and self-combustion Nano MgO catalysts and alcohol to oil mole proportion of 1:7 Waste cooking oil transesterification reaction yield in the presence of combined oxide catalysts was studied and it indicated that by combining Nano $\mathrm{CaO}$ and selfcombustion Nano $\mathrm{MgO}$ with the $3 \%$ weight percentage and alcohol to oil mole proportion of 1:7 over 6 hours, biodiesel production mass yield rose by increasing $\mathrm{CaO}$ mass proportion to $\mathrm{MgO}$. These studies show that although self-combustion Nano $\mathrm{MgO}$ does not help the transesterification reaction while combined with Nano $\mathrm{CaO}$, it increases the biodiesel production mass yield. The optimum mass proportion for $\mathrm{CaO}$ to $\mathrm{MgO}$ is 0.7:0.5 that gives a mass yield of $98.95 \%$. Results given in Table 3 show the progressive biodiesel production mass yield increased with $\mathrm{Nano} \mathrm{CaO}$ to self-combustion Nano MgO with mass proportion change (Table 5).

\section{Recycling of catalyst \\ Waste cooking oil transesterification reaction with Nano $\mathrm{CaO}$ repeatability}

After transesterification reaction in the presence of $\mathrm{CaO}$ the catalyst was separated from the main products and washed away with $\mathrm{n}$-hexane and put in a $70^{\circ}$ oven to dry. Then in optimum conditions of the reaction, repeatability was evaluated. The results and the number of repetitions are shown in Fig. 4.

\section{Waste cooking oil transesterification reaction repeatability with Nano CaO and Nano MgO catalyst by the proportion of $0.7-0.5 \mathrm{~g}$}

When the optimum mass proportion for $\mathrm{CaO}$ to selfcombustion $\mathrm{MgO}$ was determined and transesterification was over, the combination of the catalysts was separated from the main product and washed with n-hexane, then it was placed in a $70^{\circ}$ oven to dry. Eventually, repeatability was determined for the catalyst mixture in optimum conditions. The results and number of repetitions are shown in Fig. 5.

\section{FTIR analysis}

IR spectrum for methyl esters (biodiesel) is somewhat similar to oil spectrum and it rarely has some differences in the finger print area. As the only change in oil structure is the exit of glycerol and substituting methanol in hydrocarbon chain, methyl ester IR spectrum is much like triglyceride oils and the most variations are in 1000-1500 area by which can be verified by the complete synthesis of the biodiesel. The three main effective groups are shown in Table 2.

In addition, the lack of $-\mathrm{OH}$ spectrum near 3500 region implies that the transesterification reaction is performed completely and lack of intermediate compounds like free fatty acids and mono and diglycerids can be also rationalized (Fig. 5). The resulting spectrum showed that transesterification did not make any progress much in the presence of Mgo Nanocatalyst and the three main effective groups were not recognizable in the spectrum. Additionally, transesterification in the presence of catalyst mixture progressed completely and the three main effective groups emerged in the spectrum (Fig. 6).

\section{Discussion}

During the first step of tranesterification reaction in the presence of Nano $\mathrm{CaO}$, proton is absorbed from methanol by means of basic sections available in Nano $\mathrm{CaO}$ structure. This reaction results in meth oxide anion formation. Meth oxide group holds an oxygen molecule within its structure which attacks carbon from triglyceride-fatty acid's carbonyl group, resulting in alkoxycarbonyl formation as an intermediate structure. Alkoxycarbonyl transfroms itself into more stable products: fatty acid methyl ester and diglyceride. As the transformation continues, diglyceride converts to monoglyceride and fatty acid methyl ester. During the third step, monoglyceride undergoes the same reaction and produces glycerin and fatty acid methyl ester. In conclusion, fatty acid tri-methyl ester and glycerin are the final products of the reaction. The summarized version of reaction is provided below:

$\mathrm{R} 1, \mathrm{R} 2, \mathrm{R} 3$ = fatty acid carbonic chain

Table 5 The efficacy of biodiesel production in the presence of $\mathrm{CaO}+\mathrm{MgO}$ Nanocatalyst

\begin{tabular}{llllll}
\hline The Amount of Oil (gr) & The Catalyst Compound & $\begin{array}{l}\text { Alcohol: Oil } \\
\text { Mole Ratio }\end{array}$ & $\begin{array}{l}\text { Mass Percent of the Catalyst } \\
\text { Compound }\end{array}$ & Reaction's Duration (hr) & Mass Efficiency \\
\hline 40 & $\mathrm{CaO}+\mathrm{MgO}$ & $7: 1$ & $0.5 \mathrm{~g} \mathrm{CaO}+0.7 \mathrm{~g} \mathrm{MgO}=3 \%$ & 6 & 90.85 \\
40 & $\mathrm{CaO}+\mathrm{MgO}$ & $7: 1$ & $0.6 \mathrm{~g} \mathrm{CaO}+0.6 \mathrm{~g} \mathrm{MgO}=3 \%$ & 6 & 96.22 \\
40 & $\mathrm{CaO}+\mathrm{MgO}$ & $7: 1$ & $0.7 \mathrm{~g} \mathrm{CaO}+0.5 \mathrm{~g} \mathrm{MgO}=3 \%$ & 6 & 98.95 \\
40 & $\mathrm{CaO}+\mathrm{MgO}$ & $7: 1$ & $0.9 \mathrm{~g} \mathrm{CaO}+0.3 \mathrm{~g} \mathrm{MgO}=3 \%$ & 6 & 98.57 \\
\hline
\end{tabular}


Table 6 Standard test results for biodiesel were produced from waste cooking oil in the presence of combined Nano CaO and selfcombustion Nano MgO catalyst 0.7:0.5 compared to D675-01 ASTM and EN14217

\begin{tabular}{llll}
\hline Property & The Standard Value & The Permissive Range & The Measured Value \\
\hline Flash Point & D93 & Minimum Value: 130 & $150\left(^{\circ} \mathrm{C}\right)$ \\
Kinematic Viscosity in $40^{\circ} \mathrm{C}$ & $\mathrm{D} 445$ & $1.6-9$ & $4.8 \mathrm{~mm}^{2} / \mathrm{s}$ \\
Cetane Number & D613 & Minimum Value:47 & 48 \\
Saponification Number & D460 & Indefinite & 190.70 \\
Freezing Point & - & - & $-7\left({ }^{\circ} \mathrm{C}\right)$ \\
lgnition Point & - & - & $220\left(\left(^{\circ} \mathrm{C}\right)\right.$ \\
Cloud Point & D2500 & Indefinite & $4\left(^{\circ} \mathrm{C}\right)$ \\
Pour Point & ISO3016 & Maximum Value:0 & $-5\left({ }^{\circ} \mathrm{C}\right)$ \\
lodine Number & EN14111 & Maximum Value: 130 & 124.48 \\
Density & EN ISO 3675 & $0.86-0.89\left(\mathrm{gr} / \mathrm{cm}^{3}\right)$ & $0.89\left(\mathrm{gr} / \mathrm{cm}^{3}\right)$ \\
\hline
\end{tabular}

Alcohol's alkali group $=\mathrm{R} 4$

Nano $\mathrm{CaO}$ provides us with a better efficacy and using waste cooking oil is more cost-effective [16]. Optimum conditions for this catalyst is 1:7 methanol to oil, in six hours and $1.5 \%$ of catalyst's weight at which biodiesel production yield is $94.37 \%$ of weight (Table 3 ).

In 2008, Kouzu M. released an article, concerning Calcium oxide as a solid base catalyst for transesterification of soybean oil and its contribution to biodiesel production.

Soy fatty acid methyl ester production yield in the presence of $\mathrm{CaO}$ is reported $93 \%$ in one-hour time duration and methanol-oil mole proportion of 12:1 [26, 27]. In 2010, Man kee Lam provided an article, concerning Homogeneous, heterogeneous and enzymatic catalysis for transesterification of hight free fatty acid oil (waste cooking oil) to biodiesel.

It was observed that when using $0.85 \mathrm{~g} \mathrm{CaO}$ and under same conditions, yield decreases to $66 \%$ [28]. Results obtained from different studies for $\mathrm{CaO}$ indicate that (Table 4):

By comparing obtained results from this survey, and other conducted surveys, it can be concluded that Nano $\mathrm{CaO}$ can enhance trans esterification reaction's efficacy more than $\mathrm{CaO}$ owing to its high contact area. Repeatability of Nano $\mathrm{CaO}$ and the ability of reusing this catalyst were also discussed. As the results indicate, repeatability of this catalyst was satisfactory (Fig. 4).

Nano $\mathrm{MgO}$ is not catalyzing the transesterification by itself, but when used with Nano $\mathrm{CaO}$ transesterification reaction yield significantly increases. By enhancing MgO's catalytic strength and basic strength, the reaction is performed in more gentle conditions (Table 5).

The comparison of the obtained values with the standard tests indicates that they all fall within the normal range and as a result, this biodiesel is viable (Table 6).

\section{Conclusions}

As the results indicate, Nano $\mathrm{CaO}$ provides us with a better efficacy, reaction duration, repeatability, used catalyst weight percentage, methanol amount, and biodiesel production mass yield in comparison with self-combustion Nano $\mathrm{MgO}$, due to its basic nature. Nano $\mathrm{MgO}$ is not capable of catalyzing the transesterification by itself, because it has a much weaker basic affinity but when used with $\mathrm{Nano} \mathrm{CaO}$ due to its surface structure, the basic properties increase and it becomes a proper base for the catalyst so that $\mathrm{CaO}$ contact surface increases and transesterification reaction yield significantly increases as well. Needless to say that higher proportions of Nano $\mathrm{CaO}$ to Nano $\mathrm{MgO}$ lead to increase in biodiesel production mass yield. The optimum condition for this catalyst is 1:7 methanol to oil (the same ratio which is applied for Nano $\mathrm{CaO}$ ), $6 \mathrm{~h}$ and $0.7 \mathrm{~g}$ of Nano $\mathrm{CaO}$ plus $0.5 \mathrm{~g}$ of Nano $\mathrm{MgO}$ which gives the yield of $98.95 \%$ of weight. Moreover, combined catalyst repeatability is better than $\mathrm{Nano} \mathrm{CaO}$ alone. In addition, using waste cooking oil is more cost-effective.

\section{Competing interests}

The authors declare that they have no competing interests.

\section{Authors' contributions}

$K T$ have designed of the study and participated in its Conception, data analysis and interpretation, Obtained funding, and final approval of the article. YNA carried out the experiments and data collection and helped to draft the manuscript. RF participated in analysis and interpretation of data. SM participated in data collection. ED coordination and helped to data analysis, Writing the article, and Critical revision of the manuscript. All authors read and approved the final manuscript.

\section{Acknowledgements}

We gratefully acknowledge the Department of Chemistry of North Tehran Branch of Islamic Azad University for financial and technical supports.

\section{Author details}

'Department of chemistry, Islamic Azad University, North Tehran Branch, Tehran, Iran. ${ }^{2}$ Modeling and Optimization Research Center in Science and Engineering, Islamic Azad University, South Tehran Branch, Tehran, Iran. ${ }^{3}$ Nano-ophthalmology Department, Stem Cells Preparation Unit, Eye Research Center, Farabi Eye Hospital, Tehran University of Medical Sciences, Tehran, Iran. 
Received: 4 March 2014 Accepted: 4 October 2015

Published online: 23 October 2015

\section{References}

1. Murugesan A, Umarani C, Subramanian R, Nedunchezhian N. Biodiesel as an alternative fuel for diesel engines A review. Renewable Sustain Energy Rev. 2009;13:653-62.

2. Xie W, Li H. Alumni-supported potassium iodide as a heterogeneous catalyst for biodiesel production from soybean oil. J Mol Catal A Chem. 2006:255:1-9.

3. Xie W, Peng H, Chen L. Transesterification of soybean oil catalyzed by potassium loaded on alumina as a solid-base catalyst. Appl Catal A Gen. 2006;300:67-74.

4. Singh Chouhan AP, Sarma AK. Modern heterogeneous catalysts for biodiesel production. Renew Sust Energ Rev. 2011;15(4):78-4399.

5. Feng $Y$, Zhang A, Li J, He B. A continuous process for biodiesel production in a fixed bed reactor packed with cation-exchange resin as heterogeneous catalyst. Bioresour Technol. 2011;102:3607-9. ISSN 0960-8524.

6. Agarwal AK. Biofuels (alcohols biodiesel) applications as fuels for internal combustion engines. Prog Energy Combust Sci. 2007;33:233-71.

7. Dossin TF, Reyniers MF, Marin FB. Kinetics of Heterogeneously MgOCatalyzed Transesterification. Appl Catal B Environ. 2006;62:35-45. ISSN 0926-3373.

8. Dossin TF, Reyniers MF, Berger RJ, Marin GB. Simulation of heterogeneously MgO-catalyzed transesterification for fine-chemical and biodiesel industrial production. Appl Catal B Environ. 2006;67:136-48. ISSN: 0926-3373.

9. Wen G, YAN Z. Transesterification of soybean oil to Biodiesel over kalsilite catalyst. Chem Sci Eng. 2011;5(3):325-9.

10. Diserio M, Tesser R, Pengmei L. Heterogeneous catalysts for biodiesel production. Energy Fuel. 2008;22:207-17.

11. Dossin TF, Reyniers MF, Marin GB. Simulation of heterogeneously MgoCatalyzed transerterification for fine chemical andbiodiesal industrial production. Appl Catal B. 2006;67:136-48.

12. Lam MK, Lee KT. Homogeneous, heterogeneous and enzymatic catalysis for transesterification of hight free fatty acid oil (wast cooking oil) to biodiesel: Areview. Biotechnol Adv. 2010;28:500-18.

13. Kovacheva P, Arishtirova K, Vassilev S. MgO/NaX zeolite as basic catalyst for oxidative methylation of toluene with methane. Appl Catal A Gen. 2001;210:391-5. ISSN 0926-860X.

14. Yan S, DiMaggiom C. Advancements in Heterogeneous Catalsysis for Biodiesel Synthesis. Top Catal. 2010;53:721-36.

15. Bournay L, Casanave D, Delfort B, Hillion G, Chodorge JA. New heterogeneous process for biodiesel production: A way to improve the quality and the value of the crude glycerin produced by biodiesel plants. Catal Today. 2005;106:190-2. ISSN 0920-5861.

16. Zhang Y, Ma D, Mclean DD, Kates M. Biodiesel Production from waste cooking oil. Bioresour Technol. 2003;90:229-40.

17. Demirbas A. Biodiesel from sunflower oil in supercritical methanol with calcium oxide. Energy Conv Manag. 2007:48:937-41.

18. Issariyakul T, Kulkarne MG, Meher LC, Dalai AK, Bakhshi NN. Biodiesel production from mixtures of canola oil and used cooking oil. Chem Eng J. 2007;140:77-85.

19. Encinar JM, Gonzalez JF. Biodiesel from used frying oil. Variables Affecting the yields and characteristics of biodiesel. Eny Chem Res. 2005;44:5491-9.

20. Gerhard knothe JVG, Krahl J. The biodiesel hand book. Champaign: AOCS Press; 2004.

21. Kaur N, Amjad A. Lithium ion impregnated calcium oxide as Nano catalyst for the biodiesel production from karanj a and jatropha oils. Renewale Energy. 2011;36:2866-71.

22. Diserio M, Tesser R, Nasatasi M. Synthesis of biodiesel via homogeneous lewis acid catalysts. J Mol Catal. 2005;239:111-5.

23. Wang L, Yang J. Transesterification of soybean oil with noano-Mgo or not in super critical and subcritical methanol. Fuel. 2007;86:328-33.

24. Mahdavi V, Monajemi A. Optimization of operational conditions for biodiesel production from cottonseed oil on $\mathrm{CaO}-\mathrm{MgO} / \mathrm{Al} 2 \mathrm{O} 3$ solid base catalysts. J Taiwan Inst Chem Eng. 2014;45(5):2286-92.

25. Zhao L, Qiu Z, Stagg-Williams SM. Transesterification of canola oil catalyzed by nanopowder calcium oxide. Fuel Process Technol. 2013;114:154-62.

26. Kouzu M, Kasuno T, Tajika M, Yamanaka S, Hidaka J. Calcium oxide as a solid base catalyst for transesterification of soybean oil and its application to biodiesel production. Fuel. 2008;87:2798-806.
27. Granados ML, Poves MDZ, Alonso DM, Mariscal R, Galisteo FC, Santamaria J, et al. Biodiesel from sunflower oil byusing activated calcium oxide. Appl Catal B Environ. 2007;73:317-26.

28. Mk L, Lee KT. Homogeneous, heterogeneous and enzymatic catalysis for transesterification of hight free fatty acid oil (wast cooking oil) to biodiesel: Areview. Biotechnol Adv. 2010;28:500-18.

\section{Submit your next manuscript to BioMed Central and take full advantage of:}

- Convenient online submission

- Thorough peer review

- No space constraints or color figure charges

- Immediate publication on acceptance

- Inclusion in PubMed, CAS, Scopus and Google Scholar

- Research which is freely available for redistribution 